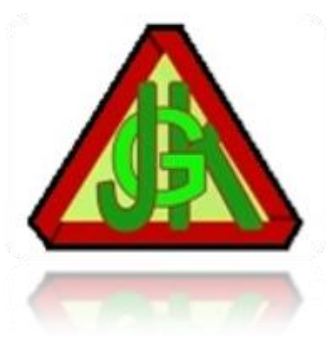

\title{
LAMA PENGGUNAAN KONTRASEPSI DEPO MEDROKSI PROGESTERON ASETAT DENGAN INDEKS MASSA TUBUH DAN KADAR KOLESTEROL TOTAL
}

\author{
Ni Luh Gede Leody Raccillia Putri ${ }^{1}$, Suratiah ${ }^{2}$, Nengah Runiari ${ }^{3}$, Dewa Ayu Ketut \\ Surinati $^{4}$, Ni Nyoman Hartati ${ }^{5}$, Dewa Made Ruspawan ${ }^{6}$ \\ 1,2,3,4,5,6 Politeknik Kesehatan Kemenkes Denpasar \\ Denpasar, Indonesia
}

\begin{abstract}
Email: raccillia@gmail.com ${ }^{1}$, suratiahpoltekkesdps@gmail.com $^{2}$, nengahruniari@gmail.com ${ }^{3}$, dwayu.surinati@yahoo.com ${ }^{4}$, $\underline{\text { ninyomanhartati@gmail.com }}^{5}$, ruspawan.dm@ gmail.com $^{6}$
\end{abstract}

\begin{abstract}
Abstrak
Kontrasepsi Depo Medroxy Progesteron Asetat adalah satu-satunya kontrasepsi hormonal yang secara konsisten memiliki efek terhadap kenaikan berat badan yang berakibat pada perubahan Indeks Masa Tubuh serta mempengaruhi profil lipid mengakibatkan peningkatan kadar kolesterol. Tujuan dari penelitian ini untuk mengetahui hubungan antara lama pemakaian kontrasepsi suntik Depo Medroxy Progesteron Asetat dengan Indeks Masa Tubuh dan kadar kolesterol total dalam darah pada pengguna Depo Medroxy Progesteron Asetat di wilayah kerja Puskesmas IV Denpasar Selatan tahun 2021. Penelitian ini menggunakan teknik pengambilan sampel non-probability sampling dengan purposive sampling sebanyak 32 responden. Instrumen pengumpulan melalui wawancara dan pengukuran Indeks Masa Tubuh dengan mengukur tinggi badan dan berat badan serta pengukuran kadar kolesterol menggunakan alat EasyTouch GCU Kit. Hasil penelitian menunjukkan bahwa sebagain besar lama pengguna kontrasepsi suntik Depo Medroxy Progesteron Asetat yaitu pemakai $\geq 24$ bulan sebanyak 22 orang 68,8\%, sebagian besar pengguna kontrasepsi suntik Depo Medroxy Progesteron Asetat memiliki IMT gemuk berat $40.6 \%$ dan kadar kolesterol normal 68,8\%, kolesterol agak tinggi $25,0 \%$ dan kolesterol tinggi $6,3 \%$. Uji hipotesis yang digunakan adalah contigency coefficient dengan nilai Indeks Masa Tubuh $\mathrm{p}=0,001 \quad(\mathrm{p}<0,05)$ dan nilai kolesterol $\mathrm{p}=0,037 \quad(\mathrm{p}<0,05)$, sehingga terdapat hubungan lama pemakaian kontrasepsi suntik Depo Medroxy Progesteron Asetat dengan Indeks Masa Tubuh dan kadar kolesterol total dalam darah pada pengguna akseptor Depo Medroxy Progesteron Asetat di wilayah kerja Puskesmas IV Denpasar Selatan tahun 2021. Berdasarkan hasil penelitian diharapkan dapat menjadi bahan pertimbangan dalam pemberian edukasi dan konseling mengenai bagaimana cara mengatasi efek samping yang terjadi, sehingga akseptor dapat mengendalikan peningkatan berat badan dan pengukuran kadar kolesterol secara rutin.
\end{abstract}

Kata Kunci: Lama Pemakaian, DMPA, IMT, Kolesterol 
Ni Luh Gede Leody Raccillia Putri, Suratiah, Nengah Runiari, Dewa Ayu Ketut Surinati, Ni Nyoman Hartati, Dewa Made Ruspawan. Juni 2021. 14 (1): $1-15$

\begin{abstract}
BMI and total blood cholesterol levels in Depo Medroxy Progesteron Asetate family planning users in the work area of Puskesmas IV Denpasar Selatan in 2021. This study used a non-probability sampling technique with purposive sampling as many as 32 respondents. Collecting instruments through interviews and measuring Basal Metabolisme Indekx by measuring height and weight and measuring cholesterol levels using the EasyTouch GCU Kit. The results showed that most of the users of injection contraceptive Depo Medroxy Progesteron Asetate were 22 people $68.8 \% \geq 24$ months, most of the users of Depo Medroxy Progesteron Asetate injection contraception had a heavy Basal Metabolisme Indekx $40.6 \%$ and cholesterol normal levels $68.8 \%$, rather high cholesterol $25.0 \%$ and high cholesterol 6.3\%. Hypothesis testing used is the contingency coefficient with a Basal Metabolisme Indekx value of $p=0.001(p<0.05)$ and a cholesterol value of $p=0.037(p<0.05)$, so there is a relationship between the length of time using Depo Medroxy Progesteron Asetate injection contraceptives and Basal Metabolisme Indekx. and total cholesterol levels in the blood in Depo Medroxy Progesteron Asetate family planning acceptors users in the work area of Puskesmas IV South Denpasar in 2021. Based on the results of the study, it is hoped that this can be taken into consideration in providing education and counseling on how to overcome the side effects that occur, so that family planning acceptors Depo Medroxy Progesteron Asetate contraceptives are the only hormonal contraceptives that consistently have an effect on weight gain which results in changes in BMI and affects the lipid profile resulting in increased cholesterol levels. The purpose of this study was to determine the relationship between the duration of use of DMPA injection contraceptives with can overcome the problem of increasing. weight arising from the use of Depo Medroxy Progesteron Asetate family planning and the importance of measuring cholesterol levels regularly in Depo Medroxy Progesteron Asetate family planning acceptors.
\end{abstract}

Keywords: Duration useage, DMPA, BMI, cholesterol

\title{
PENDAHULUAN
}

Indonesia adalah negara berkembang dengan rata-rata jumlah penduduk berada pada posisi keempat terbesar dunia setelah negara China, India dan Amerika Serikat dengan laju pertumbuhan penduduk yang masih relatif tinggi ${ }^{(1)}$. Salah satu upaya pengendalian jumlah dan laju pertumbuhan penduduk dalam Rencana Pembangunan Jangka Panjang Nasional (RPJPN) tahun 2005-2025 yaitu melalui Keluarga Berencana ${ }^{(2)}$.

Data Survei Demografi dan Kesehatan Indonesia (SDKI) tahun 2017, didapatkan tren prevalensi penggunaan kontrasepsi/Contraceptive Prevalence 
Ni Luh Gede Leody Raccillia Putri, Suratiah, Nengah Runiari, Dewa Ayu Ketut Surinati, Ni Nyoman Hartati, Dewa Made Ruspawan. Juni 2021. 14 (1): $1-15$

Rate (CPR) di Indonesia terjadi peningkatan pada pemakaian kontrasepsi dari 61,9\% ${ }^{(3)}$ menjadi 63,22\% menurut Badan Pusat Statistik. Pencapaian pemakaian metode kontrasepsi modern sebesar 57\% di Indonesia. Sebagian besar (lebih dari $80 \%$ ) peserta KB Aktif memilih jenis kontrasepsi suntik KB yaitu sebesar 62,77\% (4)

Pemakaian kontrasepsi metode modern di Kota Denpasar sebanyak 60.009 peserta $(77,94 \%)$ dari 76.995 PUS. Jumlah peserta KB suntik sebanyak 18.439 peserta (23,94\%). Jumlah pasangan usia subur di Kota Denpasar pada tahun 2019 sebanyak 79.961 orang (76,2\%) merupakan peserta KB aktif dengan persentase terbanyak berada di Puskesmas IV Denpasar Selatan yaitu sebanyak 82,6\%. Peserta KB aktif dan sebagaian adalah wanita $(94,8 \%)$ dan hanya $5,2 \%$ peserta $\mathrm{KB}$ aktif berjenis kelamin laki-laki.

Berdasarkan laporan Puskesmas IV Denpasar Selatan (2020), terdapat 2432 pasangan usia subur, yang menggunakan kontrasepsi MOW 76 orang (5,24\%), MOP 3 orang (0,21\%), IUD 1315 (90,75\%), implan 55 orang (3,80\%), suntik 503 orang $(20,68 \%)$, pil 29 orang $(5,42 \%)$, dan kondom sebanyak 3 orang $(0,56 \%)$.

KB suntik yang banyak digunakan adalah Depo Medroksiprogesteron Asetat (DMPA). Hal ini dikarenakan kontrasepsi suntik bersifat lebih aman, sederhana, efektif, dan bisa dipakai pada pasca persalinan. DMPA adalah kontrasepsi suntik progestin yang mengandung $150 \mathrm{mg}$ Depo Medroksiprogesteron asetat yang diberikan setiap 3 bulan dengan cara disuntik secara intra muskuler (IM). Mengingat jumlah akseptor kontrasepsi suntikan semakin meningkat, maka perlu diwaspadai dan antisipasi kemungkinan efek samping yang dapat terjadi.

Depo medroksiprogeseterone asetat adalah salah satu kontrasepsi hormonal yang secara konsisten berefek terhadap kenaikan berat badan. Perubahan pertambahan berat badan ini dapat dipengaruhi oleh berbagai faktor salah satunya adalah hormonal yang terkandung dalam KB Hormonal yaitu hormon estrogen dan progesterone. Adanya peningkatan berat badan ini dapat diobservasi melalui pemeriksaan Indeks Masa Tubuh (IMT). 
Ni Luh Gede Leody Raccillia Putri, Suratiah, Nengah Runiari, Dewa Ayu Ketut Surinati, Ni Nyoman Hartati, Dewa Made Ruspawan. Juni 2021. 14 (1): $1-15$

DMPA mampu mempengaruhi metabolism lemak, khususnya lipoprotein. Perubahan metabolisme lemak yang terjadi karena adanya pengaruh hormonal sehingga menyebabkan gangguan profil lipid. Saat ini telah diketahui bahwa profil lipid spesifik dapat menjadi pertanda bagi risiko aterosklerosis vaskuler. Penurunan kadar kolesterol High Density Lipoprotein (HDL) dan peningkatan kadar kolesterol Low Density Lipoprotein (LDL) merupakan risiko tinggi terjadinya aterosklerosis termasuk penyakit jantung iskemia.

Berdasarkan berbagai uraian diatas, maka peneliti berminat melakukan penelitian Tujuan dari penelitian ini untuk mengetahui hubungan antara lama pemakaian kontrasepsi suntik Depo Medroxy Progesteron Asetat dengan Indeks Masa Tubuh dan kadar kolesterol total dalam darah pada pengguna Depo Medroxy Progesteron Asetat di wilayah kerja Puskesmas IV Denpasar Selatan tahun 2021.

\section{METODE}

Rancangan penelitian ini menggunakan Analitik Korelasional dengan penelitian kuantitatif non eksperimen. Penelitian ini menggunakan pendekatan cross sectional. Pengambilan sampelnya adalah non probability sampling dengan teknik purposive sampling dengan jumlah 32 sample. Data yang didapatkan adalah Indeks Masa Tubuh dan Kadar Kolesterol Pengguna DMPA. Data diuji dengan contigency coefficient.

\section{HASIL DAN PEMBAHASAN}

Karakteristik responden yang diteliti dapat diuraikan disajikan dalam bentuk tabel berikut: 
Ni Luh Gede Leody Raccillia Putri, Suratiah, Nengah Runiari, Dewa Ayu Ketut Surinati, Ni Nyoman Hartati, Dewa Made Ruspawan. Juni 2021. 14 (1): $1-15$

Tabel 1. Distribusi Karakteristik Responden Berdasarkan Pendidikan Di Wilayah Kerja Puskesmas IV Denpasar Selatan

\begin{tabular}{lcc}
\hline \multicolumn{1}{c}{ Pendidikan } & Frekuensi (f) & Presentase (\%) \\
\hline Tidak sekolah & 0 & $0 \%$ \\
\hline SD & 4 & $12,5 \%$ \\
\hline SMP & 3 & $9,4 \%$ \\
\hline SMA/SMK & 17 & $53,1 \%$ \\
\hline Diploma/Sarjana & 8 & $25 \%$ \\
\hline Jumlah & $\mathbf{3 2}$ & $\mathbf{1 0 0 \%}$ \\
\hline
\end{tabular}

Berdasarkan tabel 1 diatas, sebagian besar responden menempuh pendidikan dan paling banyak memiliki pendidikan terakhir SMA/SMK yaitu 17 orang $(53.1 \%)$ dan hanya 4 orang $(12,5 \%)$ yang menempuh pendidikan sampai SD.

Berdasarkan hasil penelitian yang didapatkan, bahwa akseptor KB suntik sebagian besar lulusannya dari SMA/SMK. Tingkat pendidikan dinyatakan tidak menunjukkan hubungan positif dengan pemakaian jenis kontrasepsi dimana semakin tinggi tingkat pendidikan, maka cenderung memakai kontrasepsi lebih efektif.

Tabel 2. Distribusi Karakteristik Responden Berdasarkan Pekerjaan Di Wilayah Kerja Puskesmas IV Denpasar Selatan

\begin{tabular}{lcc}
\hline \multicolumn{1}{c}{ Pekerjaan } & Frekuensi (f) & Presentase (\%) \\
\hline Bekerja & 21 & $65,6 \%$ \\
\hline Tidak bekerja & 11 & $34,4 \%$ \\
\hline Jumlah & $\mathbf{3 2}$ & $\mathbf{1 0 0 \%}$ \\
\hline
\end{tabular}

Ditinjau dari tabel 2 diatas, hasilnya adalah sebagian besar responden memiliki pekerjaan yaitu sebanyak 21 orang $(65.6 \%)$ dan 11 orang $(34,4 \%)$ tidak memiliki pekerjaan.

Hasil penelitian pada saat wawancara sebagian besar responden yang mengatakan memiliki pekerjaan sebagai pedagang dan asisten rumah tangga, dan beberapa responden bekerja sebagai guru yang memiliki tingkat aktivitas ringan. Pekerjaan mempengaruhi peningkatan berat badan pada akseptor KB karena 
Ni Luh Gede Leody Raccillia Putri, Suratiah, Nengah Runiari, Dewa Ayu Ketut Surinati, Ni Nyoman Hartati, Dewa Made Ruspawan. Juni 2021. 14 (1): $1-15$

pekerjaan sangat berhubungan dengan tingkat aktivitas sehari-hari dari akseptor, semakin banyak aktivitas akseptor, maka semakin banyak energi yang dibutuhkan, sehingga peningkatan berat badan yang diamati tidak terlalu signifikan begitu pula dengan responden yang memiliki kadar kolesterol total dalam darah.

Tabel 3. Distribusi Karakteristik Responden Berdasarkan Tingkat Aktivitas Di Wilayah Kerja Puskesmas IV Denpasar Selatan

\begin{tabular}{lcc}
\hline \multicolumn{1}{c}{ Tingkat Aktivitas } & Frekuensi (f) & Presentase (\%) \\
\hline Aktivitas ringan & 24 & $75 \%$ \\
\hline Aktivitas sedang & 8 & $25 \%$ \\
\hline Aktivitas berat & 0 & $0 \%$ \\
\hline Jumlah & $\mathbf{3 2}$ & $\mathbf{1 0 0 \%}$ \\
\hline
\end{tabular}

Berdasarkan tabel 3 diatas, sampel tidak ada yang memiliki tingkat aktivitas yang berat dan sebagian besar responden memiliki tingkat aktivitas ringan yaitu sebanyak 24 orang $(75 \%)$ dan 8 orang $(25 \%)$ memiliki tingkat aktivitas sedang.

Wawancara yang dilakukan saat penelitian, responden memiliki pekerjaan yang menguras banyak waktu dan memiliki anak yang masih memerlukan bimbingan dari orang tua sehingga tidak memiliki waktu lain untuk melakukan olahraga yang merupakan tingkat aktivitas yang berat seperti jogging, berlari, mengangkat beban/gym, bermain dan bersepeda.

Kurang aktivitas fisik dapat meningkatkan berat badan. Hal ini disebabkan karena asupan energi yang melebihi kebutuhan tubuh yang biasanya dialami oleh orang yang kurang olah raga atau kurang aktivitas fisik sehingga energi yang masuk kedalam tubuh tidak akan dibakar atau digunakan kemudian disimpan dalam bentuk lemak. Penelitian lain menyatakan aktivitas fisik memiliki hubungan yang berbanding terbalik dengan kadar kolesterol LDL dengan hasil nilai koefisien korelasinya $-0,288$ dan nilai $\mathrm{p}=0,001$ yang menunjukkan bahwa hubungan antar variabel dinilai bermakna ${ }^{(5)}$. 
Ni Luh Gede Leody Raccillia Putri, Suratiah, Nengah Runiari, Dewa Ayu Ketut Surinati, Ni Nyoman Hartati, Dewa Made Ruspawan. Juni 2021. 14 (1): $1-15$

Tabel 4. Distribusi Karakteristik Rata-rata Responden Berdasarkan Usia Di Wilayah Kerja Puskesmas IV Denpasar Selatan

\begin{tabular}{ccccccc}
\hline Karakteristik & $\mathbf{N}$ & Mean & Median & Modus & $\begin{array}{c}\text { Standar } \\
\text { Deviasi }\end{array}$ & Min - Max \\
\hline Usia & 32 & 29,78 & 30.00 & 28 & 3,841 & $22-35$ \\
\hline
\end{tabular}

Berdasarkan tabel 4 diatas, dari 32 responden didapatkan bahwa rata-rata usia responden yaitu 29.78 tahun dengan usia terbanyak yaitu 28 tahun dan nilai tengah yaitu 30.00 tahun dengan standar deviasi yaitu 3.841 dan usia termuda yaitu 22 tahun dan usia tertua yaitu 35 tahun.

Umur mempengaruhi peningkatan berat badan akseptor KB karena semakin produktif usia akseptor, maka pengaruh hormonal KB akan semakin terlihat pada tubuh akseptor yang ditandai dengan peningkatan berat badan yang lebih signifikan jika dibandingkan dengan akseptor KB pada usia yang lebih tua. Tidak terdapat hubungan antara umur dengan kadar kolesterol total. Hasil tersebut terjadi karena diet dan gaya hidup adalah faktor yang terlibat dalam merangsang terjadinya peningkatan dan penurunan kadar kolesterol.

Tabel 5. Distribusi Karakteristik Rata-rata Responden Berdasarkan Berat Badan Di Wilayah Kerja Puskesmas IV Denpasar Selatan

\begin{tabular}{lcccccc}
\hline Karakteristik & N & Mean & Median & Modus & $\begin{array}{c}\text { Standar } \\
\text { Deviasi }\end{array}$ & $\begin{array}{c}\text { Min - } \\
\text { Max }\end{array}$ \\
\hline $\begin{array}{l}\text { BB sebelum } \\
\text { penggunaan } \\
\text { kontrasepsi }\end{array}$ & 32 & 58,66 & 58,00 & 53 & 8,461 & $45-80$ \\
DMPA & & & & & & \\
\hline $\begin{array}{l}\text { BB saat } \\
\text { penelitian }\end{array}$ & 32 & 62,50 & 63,00 & 58 & 7,375 & $49-80$ \\
\hline
\end{tabular}

Berdasarkan tabel 5, dari 32 responden didapatkan bahwa rata-rata berat badan responden sebelum penggunaan kontrasepsi DMPA yaitu 58,66 kg dengan berat badan terbanyak yaitu $53 \mathrm{~kg}$ dan nilai tengah yaitu 58,00 kg dengan standar deiviasi yaitu 8,461 dan berat badan paling ringan $45 \mathrm{~kg}$ dan berat badan terberat yaitu $80 \mathrm{~kg}$. sedangkan berat badan responden yang diukur saat penelitian 
Ni Luh Gede Leody Raccillia Putri, Suratiah, Nengah Runiari, Dewa Ayu Ketut Surinati, Ni Nyoman Hartati, Dewa Made Ruspawan. Juni 2021. 14 (1): $1-15$

didapatkan rata-rata berat badan responden yaitu $62.50 \mathrm{~kg}$ dengan berat badan terbanyak yaitu $58 \mathrm{~kg}$ dan nilai tengah yaitu $63.00 \mathrm{~kg}$ dengan standar deviasi yaitu 7.375 dan berat badan paling ringan yaitu $49 \mathrm{~kg}$ dan berat badan terberat yaitu 80 $\mathrm{kg}$.

Tabel 6. Distribusi Karakteristik Rata-rata Responden Berdasarkan Berat Badan Di Wilayah Kerja Puskesmas IV Denpasar Selatan

\begin{tabular}{lcccccc}
\hline Karakteristik & $\mathbf{N}$ & Mean & Median & Modus & $\begin{array}{c}\text { Standar } \\
\text { Deviasi }\end{array}$ & $\begin{array}{c}\text { Min - } \\
\text { Max }\end{array}$ \\
\hline Selisih & 32 & 3,69 & 3,00 & 0 & 4,789 & $-8-16$ \\
\hline
\end{tabular}

Berdasarkan tabel 6 diatas, dari 32 responden didapatkan bahwa rata-rata perbedaan berat badan yang dialami setelah penggunaan KB DMPA yaitu 3,69 kg dengan kenaikan berat badan terbanyak $0 \mathrm{~kg}$ dan nilai tengah yaitu $3 \mathrm{~kg}$ dengan standar deiviasi yaitu 4,789 dan terjadi penurunan berat badan hingga $8 \mathrm{~kg}$ dan kenaikan berat badan sampai $16 \mathrm{~kg}$.

Tabel 7. Distribusi Frekuensi Karakteristik Responden Berdasarkan Lama Pemakaian Kontrasepsi Suntik Depo Medroksiprogesteron Asetat Di Wilayah Kerja Puskesmas IV Denpasar Selatan

\begin{tabular}{clcc}
\hline No & $\begin{array}{c}\text { Lama Pemakaian } \\
\text { Kontrasepsi Suntik DMPA }\end{array}$ & Frekuensi (f) & Persentase (\%) \\
\hline 1 & $6-24$ bulan & 10 & $31,3 \%$ \\
\hline 2 & $\geq 24$ bulan & 22 & $68,8 \%$ \\
\hline & Jumah & $\mathbf{3 2}$ & $\mathbf{1 0 0 \%}$ \\
\hline
\end{tabular}

Berdasarkan tabel 7 diatas, dari 32 responden didapatkan bahwa sebagain besar lama pengguna kontrasepsi suntik DMPA yaitu pemakai $\geq 24$ bulan sebanyak 22 orang $(68,8 \%)$.

Hartanto mengungkapkan bahwa dari pemakaian kontrasepsi suntik jangka waktu yang lama dapat menyebabkan kenaikan berat badan karena adanya kandungan hormon progesteron yang dapat meningkatkan nafsu makan, apabila pemakaian dosis yang tinggi atau berlebihan akan dapat merangsang pusat 
Ni Luh Gede Leody Raccillia Putri, Suratiah, Nengah Runiari, Dewa Ayu Ketut Surinati, Ni Nyoman Hartati, Dewa Made Ruspawan. Juni 2021. 14 (1): $1-15$

pengendali nafsu makan di hipotalamus yang akan menyebabkan akseptor makan lebih banyak dari biasanya ${ }^{(6)}$. Semakin sering seseorang mendapatkan suntik DMPA, maka akumulasi dan pengaruh hormon terhadap metabolisme lemak juga akan meningkat ${ }^{(7)}$.

Agustiyani mengungkapkan apabila menggunakan KB suntik 3 bulan semakin lama akan menimbulkan beberapa efek samping dikarenakan pada alat ini mengandung hormon progesteron yang dapat merendahkan kadar HDL kolesterol (kolesterol baik) serta meninggikan kadar LDL kolesterol (kolesterol jahat) dalam darah sehingga menimbulkan kadar kolesterol meningkat ${ }^{(8)}$.

Berdasarkan hasil diatas dapat disimpulkan bahwa, penggunaan kontrasepsi suntik yang lama pemakaian kontrasepsi suntik DMPA 6-24 dan $\geq 24$ bulan dapat terjadi peningkatan indeks massa tubuh dan meningkatkan kadar kolesterol total dalam darah dalam jangka waktu lebih dari 24 bulan. Penggunaan kontrasepsi $\geq$ 24 bulan disebabkan karena pengguna akseptor KB DMPA merasa sudah cocok dan nyaman menggunakan kontrasepsi suntik DMPA, selain itu karena efek dari kontrasepsi selama 3 bulan membuat ibu tidak perlu untuk sering-sering mengunjungi fasilitas kesehatan. Manfaat yang dirasakan oleh ibu dalam menggunakan KB DMPA karena harga yang terjangkau dan penggunaan yang praktis tidak merasa sakit dan risih dalam penggunaan KB DMPA.

Tabel 8. Distribusi Frekuensi Karakteristik Responden Berdasarkan Indeks Massa Tubuh Di Wilayah Kerja Puskesmas IV Denpasar Selatan

\begin{tabular}{llcc}
\hline No & $\begin{array}{c}\text { Indeks Massa } \\
\text { Tubuh }\end{array}$ & Frekuensi (f) & Persentase (\%) \\
\hline 1 & Kurus berat & 0 & $0 \%$ \\
\hline 2 & Kurus ringan & 0 & $0 \%$ \\
\hline 3 & Normal & 9 & $28.1 \%$ \\
\hline 4 & Gemuk ringan & 10 & $31.3 \%$ \\
\hline 5 & Gemuk berat & 13 & $40.6 \%$ \\
\hline & Jumah & $\mathbf{3 2}$ & $\mathbf{1 0 0 \%}$ \\
\hline
\end{tabular}


Ni Luh Gede Leody Raccillia Putri, Suratiah, Nengah Runiari, Dewa Ayu Ketut Surinati, Ni Nyoman Hartati, Dewa Made Ruspawan. Juni 2021. 14 (1): $1-15$

Berdasarkan tabel 8 diatas, dari 32 responden didapatkan bahwa sebagain besar pengguna kontrasepsi suntik DMPA memiliki indeks massa tubuh gemuk berat sebanyak 13 orang (40.6\%).

Tabel 9. Distribusi Karakteristik Responden Berdasarkan Kadar Kolesterol Di Wilayah Kerja Puskesmas IV Denpasar Selatan

\begin{tabular}{|c|c|c|c|}
\hline No & Kadar Kolesterol Total & Frekuensi (f) & Persentase $(\%)$ \\
\hline 1 & Normal & 22 & $68,8 \%$ \\
\hline 2 & Agak tinggi & 8 & $25.0 \%$ \\
\hline 3 & Tinggi & 2 & $6.3 \%$ \\
\hline & Jumah & 32 & $100 \%$ \\
\hline
\end{tabular}

Berdasarkan tabel 9 diatas, sebagain besar pengguna kontrasepsi suntik DMPA memiliki kadar kolesterol normal sebanyak 22 orang $(68,8 \%)$, namun tidak sedikit pula yang memiliki kolesterol agak tinggi sebanyak 8 orang $(25,0 \%)$ dan yang memiliki kolesterol tinggi sebanyak 2 orang $(6,3 \%)$.

Tabel 10. Analisis Bivariat Hubungan Lama Penggunaan Kontrasepsi Hormonal Jenis Depo Medroksiprogesteron Asetat Dengan Indeks Massa Tubuh Di Wilayah Kerja Puskesmas IV Denpasar Selatan Tahun 2021

\begin{tabular}{|c|c|c|c|c|c|c|c|c|c|c|c|}
\hline \multirow{3}{*}{$\begin{array}{c}\text { Lama } \\
\text { Pema- } \\
\text { kaian } \\
\text { Kontra- } \\
\text { sepsi } \\
\text { Suntik } \\
\text { DMPA }\end{array}$} & & & & & & & & & \multicolumn{2}{|c|}{ Jumlah } & \multirow[t]{3}{*}{$\mathbf{P}$} \\
\hline & $\begin{array}{l}\text { Kurus } \\
\text { berat }\end{array}$ & $\begin{array}{l}\text { Kurus } \\
\text { ringan }\end{array}$ & \multicolumn{2}{|c|}{ Normal } & \multicolumn{2}{|c|}{$\begin{array}{c}\text { Gemuk } \\
\text { ringan }\end{array}$} & \multicolumn{2}{|c|}{$\begin{array}{l}\text { Gemuk } \\
\text { berat }\end{array}$} & & & \\
\hline & F $\%$ & $\%$ & $\mathbf{F}$ & $\%$ & $\mathbf{F}$ & $\%$ & $\mathbf{F}$ & $\%$ & $\mathbf{F}$ & $\%$ & \\
\hline $\begin{array}{l}6-24 \\
\text { bulan }\end{array}$ & $0 \quad 100 \%$ & $0 \quad 100 \%$ & 7 & $70,0 \%$ & 3 & $30,0 \%$ & 0 & $100 \%$ & 10 & $100 \%$ & 0.001 \\
\hline $\begin{array}{l}\geq 24 \\
\text { bulan }\end{array}$ & $0 \quad 100 \%$ & $0 \quad 100 \%$ & 2 & $9,1 \%$ & 7 & $31,8 \%$ & 13 & $59,1 \%$ & 22 & $100 \%$ & \\
\hline Jumlah & $0 \quad 100 \%$ & $\begin{array}{ll}0 & 100 \% \\
\end{array}$ & 9 & $28.1 \%$ & 10 & $31.3 \%$ & 13 & $40.6 \%$ & 32 & $100 \%$ & \\
\hline
\end{tabular}

Berdasarkan tabel 10, dari 32 responden didapatkan bahwa sebagian besar responden dengan lama penggunaan kontrasepsi suntik DMPA selama 6-24 Bulan memiliki indeks massa tubuh yang normal dengan persentase $70,0 \%$, sedangkan 
Ni Luh Gede Leody Raccillia Putri, Suratiah, Nengah Runiari, Dewa Ayu Ketut Surinati, Ni Nyoman Hartati, Dewa Made Ruspawan. Juni 2021. 14 (1): $1-15$

responden dengan lama pengguunaaan kontrasepsi depo medroksiprogesteron asetat selama $\geq 24$ bulan sebagaian besar memiliki indeks massa tubuh yang tergolong gemuk berat dengan persentase 59,1\%. Hasil analisis bivariat menggnakan uji contigency coefficient dan diperoleh nilai $\mathrm{p}=0,001(\mathrm{p}<\alpha$ $(0,05))$, maka Ho ditolak dan Ha diterima. Hal ini berarti bahwa ada hubungan lama pemakaian kontrasepsi suntik depo medroksiprogesteron asetat dengan indeks massa tubuh pada pengguna akseptor KB DMPA di wilayah kerja Puskesmas IV Denpasar Selatan tahun 2021.

Peningkatan IMT terjadi dikarenakan kandungan hormon progesteron dapat meningkatkan nafsu makan. Penggunaannya dengan dosis yang tinggi dan dalam waktu yang lama sangat berisiko untuk terjadinya peningkatan IMT.

Menurut peneliti, indeks massa tubuh sangatlah bervariasi karena dapat dilihat dari lama pemakaian kontrasepsi, usia dan tingkat aktivitas yang dilakukan. Maka dari itu, pemberian DMPA dalam jangka waktu yang lama dapat meningkatkan IMT dan dampak selanjutnya yang paling sering adalah obesitas. Obesitas adalah keadaan berlebihnya asupan energi yang masuk (calory intake) tanpa diiringi dengan pembakaran energi (calory output) yang cukup, sehingga energi yang masuk berlebih yang akan disimpan di dalam tubuh sebagai lemak sehingga mengakibatkan pertambahan akumulasi berat badan.

Langkah lain yang dapat diambil dalam mencegah penambahan berat badan yang berdampak pada peningkatan IMT pada akseptor KB suntik 3 bulan adalah pembatasan makanan, diit yang seimbang dan rajin berolah raga. Akseptor KB DMPA sebaiknya berkonsultasi dahulu kepada petugas kesehatan tentang jenis penggunaan kontrasepsi selain KB suntik yang memiliki efek samping yang tidak terlalu berbahaya terhadap kesehatan bagi dirinya. Tenaga kesehatan perlu meningkatkan penyuluhan kepada akseptor KB tentang bagaimana cara mengatasi efek samping yang terjadi, sehingga akseptor KB dapat mengatasi masalah peningkatan berat badan yang timbul akibat penggunaan KB suntik 3 bulan. 
Ni Luh Gede Leody Raccillia Putri, Suratiah, Nengah Runiari, Dewa Ayu Ketut Surinati, Ni Nyoman Hartati, Dewa Made Ruspawan. Juni 2021. 14 (1): $1-15$

Tabel 11. Analisis Bivariat Hubungan Lama Penggunaan Kontrasepsi Hormonal Jenis Depo Medroksiprogesteron Asetat Dengan Kadar Kolesterol Total Dalam

Darah Di Wilayah Kerja Puskesmas IV Denpasar Selatan Tahun 2021

\begin{tabular}{|c|c|c|c|c|c|c|c|c|c|}
\hline \multirow{3}{*}{$\begin{array}{c}\text { Lama } \\
\text { Pemakaian } \\
\text { Kontrasepsi } \\
\text { Suntik } \\
\text { DMPA }\end{array}$} & & & & & & & \multicolumn{2}{|c|}{ Jumlah } & \multirow[t]{3}{*}{$\mathbf{p}$} \\
\hline & \multicolumn{2}{|l|}{ Normal } & \multicolumn{2}{|l|}{$\begin{array}{c}\text { Agak } \\
\text { Tinggi }\end{array}$} & \multicolumn{2}{|l|}{ Tinggi } & & & \\
\hline & $\mathbf{F}$ & $\%$ & $\mathbf{F}$ & $\%$ & $\mathbf{F}$ & $\%$ & $\mathbf{F}$ & $\%$ & \\
\hline $6-24$ bulan & 10 & $100 \%$ & 0 & $100 \%$ & 0 & $100 \%$ & 10 & $100 \%$ & 0.037 \\
\hline$\geq 24$ bulan & 12 & $54,5 \%$ & 8 & $36,4 \%$ & 2 & $9,1 \%$ & 22 & $100 \%$ & \\
\hline Jumlah & 22 & $68,8 \%$ & 8 & $25,0 \%$ & 2 & $6.3 \%$ & 32 & $100 \%$ & \\
\hline
\end{tabular}

Berdasarkan tabel 11, dari 32 responden didapatkan bahwa sebagian besar responden dengan lama penggunaan kontrasepsi suntik DMPA selama $6-24$ bulan, memiliki kadar kolesterol normal dengan persentase $100 \%$, sedangkan responden dengan lama penggunaan kontrasepsi depo medroksiprogesteron asetat selama $\geq 24$ bulan sebagaian besar memiliki kadar kolesterol normal dengan persentase 54,5\%. Namun tidak sedikit yang memiliki kadar kolesterol agak tinggi yaitu $8(36,4 \%)$ responden dan $2(6,3 \%)$ responden dengan kadar kolesterol yang tinggi. Hasil analisis bivariat menggunakan uji contigency coefficient dan diperoleh nilai $\mathrm{p}=0,037(\mathrm{p}<\alpha(0,05))$, sehinggan Ho ditolak dan Ha diterima. Hal ini berarti bahwa ada hubungan lama pemakaian kontrasepsi suntik depo medroksiprogesteron asetat dengan kadar kolesterol total dalam darah pada pengguna akseptor KB DMPA di wilayah kerja Puskesmas IV Denpasar Selatan tahun 2021.

KB suntik DMPA mempengaruhi metabolisme lemak, khususnya lipoprotein. Perubahan metabolisme lemak terjadi karena adanya pengaruh hormonal sehingga menyebabkan gangguan keseimbangan profil lemak dalam tubuh atau dyslipidemia. Perubahan ini mulai tampak dalam beberapa minggu setelah penyuntikan. KB suntik DMPA juga dapat mengakibatkan kenaikan berat badan karena hormon progesteron mempermudah perubahan karbohidrat dan gula menjadi lemak yang akan disimpan di bawah kulit, selain itu hormon progesteron juga menyebabkan nafsu makan bertambah dan menurunkan aktivitas fisik ${ }^{(9)}$. 
Ni Luh Gede Leody Raccillia Putri, Suratiah, Nengah Runiari, Dewa Ayu Ketut Surinati, Ni Nyoman Hartati, Dewa Made Ruspawan. Juni 2021. 14 (1): $1-15$

Kadar kolesterol pada setiap individu berbeda karena banyak faktor yang mempengaruhi seperti intake makanan yang tinggi lemak, gaya hidup dan aktifitas fisik. Kelebihan kolesterol karena sering mengonsumsi makanan tinggi kolesterol dan kurangnya aktifitas fisik akan menyebabkan gangguan pada sistem trasportasi darah baik secara langsung maupun tidak langsung.

Faktor yang dapat mempengaruhi meningkatnya kolesterol diantaranya usia, lama penggunaan, aktifitas fisik, asupan makanan dan obesitas. Dalam upaya untuk mencegah terjadinya efek samping maka pengguna KB DMPA di anjurkan untuk melakukan konseling dengan petugas kesehatan atau melakukan pemeriksaan profil lipid secara rutin serta melakukan perubahan gaya hidup dengan berolahraga dan menjaga pola makan sehat agar tidak terjadi peningkatan pada kolesterol ${ }^{(8)}$.

\section{SIMPULAN}

Berdasarkan hasil penelitian dan pembahasan di atas tentang hubungan lama penggunaan kontrasepsi hormonal DMPA dengan indeks massa tubuh dan kadar kolesterol total dalam darah di wilayah kerja Puskesmas IV Denpasar Selatan tahun 2021 terhadap 32 responden dapat disimpulkan bahwa pengguna akseptor KB suntik DMPA di wilayah kerja Puskesmas IV Denpasar Selatan sebagian besar lama pemakaian kontrasepsi suntik DMPA yaitu $>24$ bulan sebanyak 22 responden dengan persentase $68,8 \%$.

Akseptor KB suntik DMPA di wilayah kerja Puskesmas IV Denpasar Selatan sebagian besar memiliki indeks massa tubuh yang tergolong sangat gemuk yaitu sebanyak 13 respnden dengan persentase 40,6\%

Akseptor KB suntik DMPA di wilayah kerja Puskesmas IV Denpasar Selatan sebagian besar memiliki kadar kolesterol yang normal $22(68,8 \%)$ responden dan diikuti dengan $8(25,0 \%)$ responden yang memiliki kolesterol agak tinggi dan 2 (6,3\%) responden memiliki kadar kolesterol yang tinggi.

Ada hubungan bermakna antara lama penggunaan kontrasepsi depo medroksiprogesteron asetat dengan indeks massa tubuh dan kadar kolesterol total 
Ni Luh Gede Leody Raccillia Putri, Suratiah, Nengah Runiari, Dewa Ayu Ketut Surinati, Ni Nyoman Hartati, Dewa Made Ruspawan. Juni 2021. 14 (1): $1-15$

dalam darah di wilayah kerja Puskesmas IV Denpasar Selatan tahun 2021 dengan nilai $\mathrm{p}=0,001$ Nilai didapatkan $(\mathrm{p}<\alpha(0,05))$ mengalami kenaikan pada indeks massa tubuh dan $\mathrm{p}=0,037(\mathrm{p}<\alpha(0,05))$ mengalami peningkatan pada kadar kolesterol total dalam darah.

\section{UCAPAN TERIMA KASIH}

Peneliti mengucapkan terimakasih kepada kepala Puskesmas IV Denpasar Selatan beserta seluruh staf, yang telah berkenan memfasilitasi dalam melaksanakan studi pendahuluan dan membantu selama proses penelitian.

\section{ETHICAL CLEARENCE}

Persetujuan etik dalam penelitian ini diperoleh di komisi etik penelitian (KEPK) Poltekkes Kemenkes Denpasar Nomor: LB.02.03/EA/KEPK/0268/2021.

\section{DAFTAR RUJUKAN}

1. Central Intelligence Agency. The World Factbook - Country Comparison: Population. CIA Office of Public Affairs. 2017.

2. BKKBN. Survei Demografi Dan Kesehatan: Kesehatan Reproduksi Remaja 2017. Badan Kependud dan Kel Berencana Nas. 2017;

3. Kemenkes RI. Survey Demografi dan Kesehatan Indonesia. Survei Demografi dan Kesehatan Indonesia 2017. 2017.

4. Kementerian Kesehatan RI Badan Penelitian dan Pengembangan. Hasil Utama Riset Kesehatan Dasar. Kementrian Kesehatan Republik Indonesia. 2018.

5. Sari F. Studi Komparasi Kadar Glukosa Darah Sewaktu akseptor KB suntik kombinasi dan progestin di Bpm Yosi Trihana Kabupaten Klaten Jawa Tengah. J Kesehat. 2017;8.

6. Hartanto. Keluarga Berencana dan Kontrasepsi. Jakarta : Sinar Harapan.; 2010.

7. Dalam T, Ngesti, Herawati, Tutik, Saragih L. Lama Pemakaian Alat Kontrasepsi Hormonal Suntik DMPA dan Gangguan Kardiovaskuler Poltekkes Kemenkes Malang. 2015;

8. Agustiyanti, Fatimah, Aruben. Hubungan Asupan Makanan Aktivitas Fisik dan Penggunaan Kontrasepsi Hormonal dengan Kadar Kolesterol darah (Studi Pada Wanita Keluarga Nelayan usia 30-40 tahun Di Tambak Lorok Semarang tahun 2017. 2017;

9. Ratna Novalia Sari. Kontrasepsi Hormonal Suntik Depo 
Ni Luh Gede Leody Raccillia Putri, Suratiah, Nengah Runiari, Dewa Ayu Ketut Surinati, Ni Nyoman Hartati, Dewa Made Ruspawan. Juni 2021. 14 (1): $1-15$

Medroxyprogesterone Acetate (DMPA) sebagai Salah Satu Penyebab Kenaikan Berat Badan. 2015; 